\title{
The role of the degree of use of the facilities in the port choice process: the Spanish dockside cranes case
}

\author{
Ana Martínez-Pardo $(*)^{1}$, Lorena Garcia-Alonso ${ }^{2}$ and Alfonso Orro ${ }^{3}$ \\ ${ }^{1}$ Universidade da Coruña, Group of Railways and Transportation Engineering \\ ETS Ingenieros de Caminos, Canales y Puertos \\ Elviña, 15071 A Coruña, Spain \\ http : //orcid.org/0000-0002-5929-0618 \\ E-mail: ana.martinez.pardo@udc.es \\ (*) Corresponding author \\ 2 Applied Economics Department, Regional Economics Laboratory (REGIOlab) \\ University of Oviedo, Spain \\ http://orcid.org/0000-0001-8318-2492 \\ E-mail: lorena@uniovi.es \\ ${ }^{1}$ Universidade da Coruña, Group of Railways and Transportation Engineering \\ ETS Ingenieros de Caminos, Canales y Puertos \\ Elviña, 15071 A Coruña, Spain \\ http://orcid.org/0000-0003-0688-3417 \\ E-mail: aorro@udc.es
}

\begin{abstract}
The aim of this study is to analyse how the degree of use of port facilities influences the port choice process. In order to achieve that goal, a multinomial logit model was firstly proposed and then applied to a case study. In this particular case, the relationship between the container traffic and the availability of cranes was considered for the main Spanish peninsular container ports. From the obtained results, it can be concluded that the port throughput contributes positively to attract traffic because of the economies of agglomeration and the scale and network effects achieved; however, there is a threshold of traffic beyond which the attractiveness of ports decreases. The proposed methodological approach also allows to obtain the functional form of the analysed relationship without establishing it a priori.

Keywords: shipping logistics; port competition; container traffic; port facilities congestion; saturation threshold; ship-to-shore gantry cranes; decision making; discrete choice theory; DCM; multinomial logit model; Spanish port system.
\end{abstract}


Reference to this paper should be made as follows: Martínez-Pardo, A., Garcia-Alonso, L. and Orro, A. (2018) 'The role of the degree of use of the facilities in the port choice process: the Spanish dockside cranes case', Int. J. Shipping and Transport Logistics, Vol. 10, Nos. 5/6, pp.514-532.

Available online: 28 Sep 2018

DOI: 10.1504/IJSTL.2018.10016513

http://www . inderscience.com/info/inarticle.php?artid=95221

Biographical notes: Ana Martínez-Pardo is a researcher at the University of A Coruna (UDC). She has a Master degree from the UDC in Civil Engineering (Roads, Canals and Ports), and from the University Institute in Maritime Studies at UDC (Port Management and Maritime Administration). She has a PhD from UDC on modelling port choice with discrete choice models. Her research focuses on maritime economics, discrete choice models, transport planning, travel, demand forecasting and urban mobility.

Lorena Garcia-Alonso is an Associate Professor at the Department of Applied Economics of the Universidad de Oviedo, Spain. She has a PhD from the Universidad de Oviedo, with the subject: Inter-port Competition in Spain. She has authored numerous papers related to this topic in international conferences and journals. She is a member of the International Association of Maritime Economics (IAME), Regional Science Association International (RSAI), European Regional Science Association (ERSA), Spanish Association of Regional Science (AECR) and Economics Free Association (ALDE). She is also founding partner of the journal Regional Studies and founding member of the researching group Regional Economic Analysis Laboratory (REGIOlab).

Alfonso Orro Arcay is an Associate Professor of Transport Engineering and Infrastructures at the Department of Civil Engineering of the University of A Coruna (Spain). He holds an MSc in Civil Engineering (University of Cantabria), a MicroMaster in Supply Chain Management (MITx) and a PhD with a thesis on modelling of transport demand (University of A Coruña). He is currently co-Director of the Master in Logistics and Transport. He has authored numerous papers in international journals and conferences on issues related to transport planning, discrete choice models, sustainable mobility and railway engineering.

This paper is a revised and expanded version of a paper entitled "The role of the saturation of dockside cranes in the port choice process: The Spanish case" presented at IAME 2016 Conference, Hamburg, Germany, August 23-26, 2016. 


\section{Introduction}

The extraordinary growth in international trade over the last decade has put a strain on a significant part of the port industry. The International Transport Forum within the OECD (ITF) acknowledged that congestion was a problem in many ports around the world (ITF, 2009). In 2009 the ITF stated that tremendous efforts have been made to resolve the problem at both policy and research levels (ITF, 2009), but in practice no significant progress has been made and recently, the Federal Maritime Commissioners of USA (FMC) again encouraged study in this area (FMC, 2015).

This paper delves into the study of how the degree of use of port facilities may influence port choice. In this line, the ITF point out: "When a port or its hinterland facilities are more strongly congested than is the case for competing ports, the quality of that port's service may be lower in that it takes more time to access and egress the port and the reliability of service declines, and this weakens its competitive position"(International Transport Forum (ITF), 2009). There are plenty of studies about the impact of congestion on roads, as well as studies on the economic cost of urban congestion, but there do not appear to be so many on the consequences of congestion within ports.

Our working hypothesis to analyse how the degree of use of port facilities may influence port choice is: the more traffic a port has, the more attractive it becomes because of the economies of agglomeration, scale and network effects but only up to a certain point when the port starts to be saturated. From there, as port traffic continues to grow, ceteris paribus, its attractiveness starts to decrease due the negative consequences of saturation. This hypothesis is represented in Figure 1.

Figure 1: Degree of use of port facilities vs attractiveness of the port: a saturation threshold

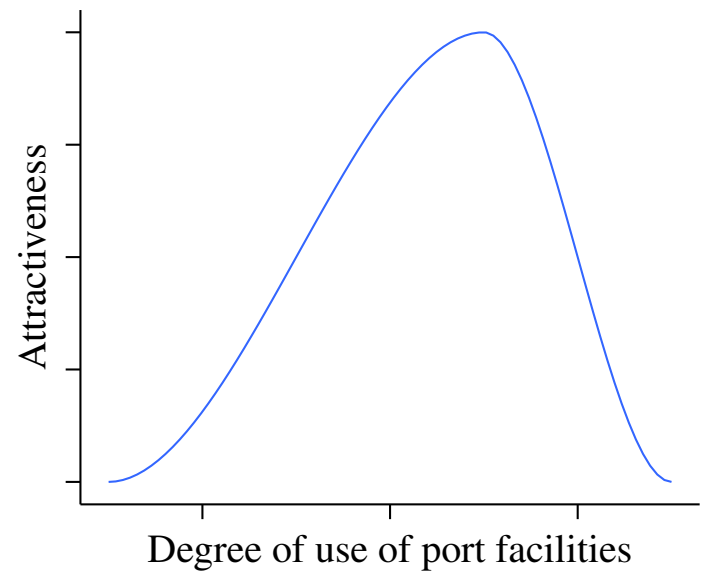

In the rising part of the curve three effects are combined, and they predominate: [i] economies of scale, larger ships help lower unit transport costs, and lower cost attract more cargo; [ii] economies of agglomeration, the more traffic, the more activity in the port, and more activity involves greater variety of services and better conditions of quality and cost; and [iii] network effects, they arise when the volume of traffic allows an increase in the frequency of the routes, which results in an increase in the attractiveness of the port. This phenomenon is also known as the "Mohring effect" (Mohring, 1972). A review of the literature about economies of scale and 
agglomeration in port scope can be found in Tovar et al. $(2003,2007)$; in relation to network effects, see Veldman et al. (2011). The studies of Tiwari et al. (2003); Yeo et al. (2014) and Slack (1985) stand out, highlighting a significant (negative) relationship between congestion and port election.

The hypothesis will be tested with 6 million contaniner exports for the four main Spanish peninsular container ports between 2004 and 2012. To address it, a Discrete Choice Model (DCM) has been proposed.

The paper is organized as follows. In Section 2 we provide an overview of the methodological approach. In Section 3, the literature review on port choice from the perspective of DCM is presented. In Section 4 we define the degree of use of port facilities indicator. In Section 5 the framework of DCM and the model proposed, is described. The data is described in Section 6. The empirical results are presented and discussed in Section 7. Finally, in Section 8 we outline the conclusions and direction for further research.

\section{Methodological approach}

Recent literature reviews on port choice can be found at Martínez Moya and Feo Valero (2016) and Parola et al. (2016). In these studies it can be seen that a great deal of research has been carried out dealing with this topic. The most common approaches have been the Analytic Hierarchy Process, the Factor Analysis, the Fuzzy Analytic Network Process and the Discrete Choice Theory. In this study, a Discrete Choice Model (DCM) has been proposed to address the suggested analysis.

Daniel McFadden won the Nobel prize in 2000 for his pioneering work in developing the theoretical basis for discrete choice (McFadden, 2001). McFadden (1973) formulated an econometric model in which the probability of choosing an alternative is defined as the probability that the alternative has the greatest utility among the set of possible alternatives. DCM are appropriate when describing or predicting the behaviour of a decision maker who chooses between several options (choice set). Its purpose is not to apply them to a particular choice, but to study how it would affect a change in one of the explanatory variables of the model in the probability of choosing each of the alternatives. Discrete choice analysis has become a standard tool not only in the planning and operation of transportation system facilities but also in marketing, finance, political science and applied economics.

The economic interpretation of DCM is based on the utility generated for the products or services assuming a utility-maximization behaviour (see e.g., Ben-Akiva and Lerman, 1985). When applying them to port choice analysis, it is assumed that shipping $n$ chooses port $j$ because such port provides the highest utility for that flow of traffic. The utility $U_{n j}$ contains a variety of variables relating to port alternative $j$ and the shipping $n$. The linear in parameters specification with attributes in natural form is the most common. To specify non-linear influence of the attributes in the utility value, we can do it using, among other, logarithms or powers. It can be introduced in the utility function and tested in the model estimation. A way to study non-linearity without the need to set it a priori is to divide the attribute into ranges by using dummy variables and estimate separate coefficients for each category. This is the approach this study uses to test the stated hypothesis. 


\section{Literature review on port choice from the Discrete Choice Models' perspective}

There are many factors that can determine port choice, all of a different nature. To name a few, the cost and the transit time, from both the inland and the maritime point of view (i.e. location with respect to production and consumption centers or with respect to the main navigation routes), quality and speed of port operations, availability of adequate infrastructures and facilities or the frequency of the commercial lines. Table 1 shows the variables considered in the main published DCM analysing the port choice. The geographical area under analysis and the data source used are also shown. Non-significant variables (or with an unexpected sign) are also listed when they are highlighted in the original papers.

Despite the fact that efficient management of operations and full utilization of the available resources are major goals in port planning, there are few studies on the subject. In relation to port operations, the availability of port services was investigated (Tongzon and Sawant, 2007), efficiency (Blonigen and Wilson, 2006; Tongzon and Sawant, 2007), as well as its reliability (Anderson et al., 2009). In relation to the utilization of the available resources, the study that comes closest is Steven and Corsi (2012). They state that port congestion and crane productivity appear to significantly affect the choice of a port. They use crane productivity as a measure to capture the speed of vessel operations at a port (average number of crane moves per hour) and port congestion as a ratio of the average total number of container vessel calls per month to a port to its available berths. They approach both in a linear way.

In this study we take the viewpoint of the utilization of the available resources and aim to identify a saturation threshold beyond which the attractiveness of the port decreases. Therefore, we need to specify a non-linear influence of the attribute in the utility value ${ }^{1}$. For this purpose, we analyse a new attribute, not previously studied, namely the degree of utilization, which can influence other variables whose effects (cost, port services, Mohring effect, port congestion) have been studied in isolation and linearly.

\section{Degree of use of port facilities indicator}

Usually, the port industry uses the technical or physical characteristics of the terminals as imput and port traffic (containers or cargo tonnes) as output (Drewry, 2014; Nuñez and Sánchez, 2006; International Transport Forum (ITF), 2014). This is due to both the fact that they reflect the most important and expensive infrastructures and equipment assets as well as being data which is easily available. The main technical or physical characteristics of a container terminal are its quay lines, yard and ship-to-shore gantry cranes (STS) commonly used in Port Performance Indicators (PPIs), which are indicators created to quantify and simplify available port information. For a review of the main approaches, see for instance González and Trujillo (2009); Ha et al. (2017); or Wilmsmeier et al. (2013).

STS crane productivity varies greatly depending on the crane's type, size, lifting equipment and level of automation. It also depends, however, on many other factors such as handling strategies, the trailer service to and from the crane or the information system. For port efficiency, the cranes must be in line with the rest of infrastructures of the port, the workforce and the size of vessels that usually use the port. According to Wilmsmeier et al. (2013) and Bichou (2013), when the number of STS cranes are used in PPIs, they capture the efficiency of the 


\begin{tabular}{|c|c|c|c|c|}
\hline \multirow[t]{2}{*}{ Reference } & \multirow{2}{*}{$\begin{array}{l}\text { Geog. } \\
\text { Area }\end{array}$} & \multirow[t]{2}{*}{ Data } & \multicolumn{2}{|l|}{ Variables } \\
\hline & & & Significant & Non-significant \\
\hline $\begin{array}{l}\text { Malchow } \\
\text { and } \\
\text { Kanafani } \\
(2001)\end{array}$ & USA & PIERS & Maritime and inland distance & $\begin{array}{l}\text { Frequency. } \\
\text { Vessel capacity }\end{array}$ \\
\hline $\begin{array}{l}\text { Nir et al. } \\
(2003)\end{array}$ & Taiwan & $\begin{array}{l}\text { Survey } \\
\text { (shippers) }\end{array}$ & $\begin{array}{l}\text { Highway transit time and cost. Number } \\
\text { of routes. Recurring user. }\end{array}$ & $\begin{array}{l}\text { Frequency. } \\
\text { Closeness to port } \\
\text { chosen }\end{array}$ \\
\hline $\begin{array}{l}\text { Blonigen } \\
\text { and Wilson } \\
(2006)\end{array}$ & USA & $\begin{array}{c}\text { US } \\
\text { Customs } \\
\text { and Border } \\
\text { (import) }\end{array}$ & $\begin{array}{l}\text { Maritime and Inland Costs. Port } \\
\text { Efficiency. }\end{array}$ & \\
\hline $\begin{array}{l}\text { Tongzon } \\
\text { and Sawant } \\
(2007)\end{array}$ & $\begin{array}{l}\text { Singa- } \\
\text { pure and } \\
\text { Malaysia }\end{array}$ & $\begin{array}{c}\text { Survey } \\
\text { (shipping } \\
\text { line) }\end{array}$ & Infrastructure. Port charges. Port services & $\begin{array}{l}\text { Connectivity. } \\
\text { Efficiency. } \\
\text { Depp-water port. } \\
\text { Vessel size }\end{array}$ \\
\hline $\begin{array}{l}\text { Anderson } \\
\text { et al. } \\
(2009)\end{array}$ & USA & PIERS & $\begin{array}{l}\text { Inland distance and maritime transit } \\
\text { time. Freight charge. Truck trip one way } \\
\text { or return. Port reliability. Coastal } \\
\text { variables: same coastal side of supplier } \\
\text { or major market }\end{array}$ & \\
\hline $\begin{array}{l}\text { Garcia- } \\
\text { Alonso and } \\
\text { Sanchez- } \\
\text { Soriano } \\
(2009)\end{array}$ & $\begin{array}{l}\text { Spanish } \\
\text { penin- } \\
\text { sula }\end{array}$ & $\begin{array}{l}\text { Spanish } \\
\text { Customs } \\
\text { Statistics }\end{array}$ & Inland distance & \\
\hline $\begin{array}{l}\text { Veldman } \\
\text { and } \\
\text { Gopkalo } \\
\text { (2011) }\end{array}$ & Russia & $\begin{array}{l}\text { Russian } \\
\text { container- } \\
\text { ised }\end{array}$ & $\begin{array}{l}\text { Inland time and cost. Maritime time and } \\
\text { cost. South Basis routing }\end{array}$ & \\
\hline $\begin{array}{l}\text { Veldman et } \\
\text { al. (2011) }\end{array}$ & $\begin{array}{l}\text { Spanish } \\
\text { penin- } \\
\text { sula }\end{array}$ & $\begin{array}{l}\text { Spanish } \\
\text { Customs } \\
\text { Statistics }\end{array}$ & $\begin{array}{l}\text { Inland cost. Maritime cost. Total cost. } \\
\text { Port quality service (Mohring effect) }\end{array}$ & \\
\hline $\begin{array}{l}\text { Steven and } \\
\text { Corsi } \\
(2012)\end{array}$ & $\begin{array}{l}\text { Pitts- } \\
\text { burgh } \\
\text { metropoli- } \\
\text { tan area } \\
\text { (USA) }\end{array}$ & PIERS & $\begin{array}{c}\text { Maritime and Inland transit time. Crane } \\
\text { productivity. Port Congestion. } \\
\text { Frequency. Form of port governance. } \\
\text { Ocean freight charges. Port size. Shipper } \\
\text { size }\end{array}$ & Vessel size \\
\hline $\begin{array}{l}\text { Veldman et } \\
\text { al. (2013) }\end{array}$ & $\begin{array}{l}\text { Spanish } \\
\text { penin- } \\
\text { sula }\end{array}$ & $\begin{array}{l}\text { Spanish } \\
\text { Customs } \\
\text { Statistics }\end{array}$ & $\begin{array}{l}\text { Coastal side. Inland and maritime cost. } \\
\text { Back-haul effect. Mohring effect }\end{array}$ & \\
\hline $\begin{array}{l}\text { Vega et al. } \\
(2014)\end{array}$ & $\begin{array}{l}\text { Colom- } \\
\text { bia }\end{array}$ & DIAN & $\begin{array}{c}\text { Oceanic cost and time. Inland Cost. } \\
\text { Frequency. Coastal side. Containerized } \\
\text { cargo }\end{array}$ & \\
\hline $\begin{array}{l}\text { Veldman et } \\
\text { al. (2015) }\end{array}$ & $\begin{array}{l}\text { Spanish } \\
\text { penin- } \\
\text { sula }\end{array}$ & $\begin{array}{l}\text { Spanish } \\
\text { Customs } \\
\text { Statistics }\end{array}$ & $\begin{array}{l}\text { Inland time and cost. Maritime cost. } \\
\text { Non-monetary cost at sea and in port. } \\
\text { Feeder port. Mohring effect }\end{array}$ & \\
\hline $\begin{array}{l}\text { Yang et al. } \\
(2016)\end{array}$ & $\begin{array}{c}\text { Bohai } \\
\text { Bay } \\
\text { (China) }\end{array}$ & China Ports & $\begin{array}{c}\text { Destination trade markets. Rapid } \\
\text { boutique lines. Hinterland's GDP. Port } \\
\text { capacity }\end{array}$ & $\begin{array}{l}\text { Foreign } \\
\text { investment in } \\
\text { Port. Highway } \\
\text { mileage }\end{array}$ \\
\hline $\begin{array}{l}\text { Kashiha et } \\
\text { al. (2016) }\end{array}$ & Austria & PIERS & $\begin{array}{l}\text { Inland and maritime distance. Border } \\
\text { count. Route infrastructure. Efficiency. } \\
\text { Connectivity. Mediterranean hub. } \\
\text { Geographical circumstances (coastal, } \\
\text { landlocked, pseudo-landlocked). Shipper } \\
\text { size, shipment volume and value }\end{array}$ & \\
\hline
\end{tabular}

Table 1: Classification of references using DCM to study Port Choice 
terminal. In fact, this value is half of the theoretical values that manufacturers report UNCTAD (2015).

The Equation (1) defines the indicator we propose to assess the degree of use of port facilities (TC). It is based on the container traffic handled by the ship-to-shore (STS) per gantry cranes per year. As a measure of container traffic, the number of twenty-foot equivalent units (TEUs) are used. All container movements are considered, regardless of whether or not they are empty. No differentiation is made between different types, sizes and lifting equipment of STS gantry cranes.

$$
T C_{j}(t)=\frac{T E U_{j}(t)}{C R_{j}(t)}
$$

where:

- $T E U_{j}(t)$ : Container traffic in TEUs moved by port $j$ in year $t$.

- $C R_{j}(t)$ : STS gantry cranes at port $j$, year $t$.

We aim to validate the hypothesis that the influence of $T C$ is not linear: the more traffic a port has, the more attractive it becomes, but only up to a certain point when the port starts to be saturated. The methodology set out below allows us to obtain the functional form of the relation between the degree of use and the port attractiveness without setting it a priori. For a description of the data used here to illustrate the methodology, see Section 6.

The first step is to divide the attribute into ranges. So, after computing $T C_{j}$ we form categories, also called class intervals, by dividing the continuous variable $T C_{j}$ into $q$ segments. We divided it into four equal-sized classes: A, B, C, D (see Equation (2)). Another division of intervals can be chosen, see Section 7 for an adjustment of intervals to the case study.

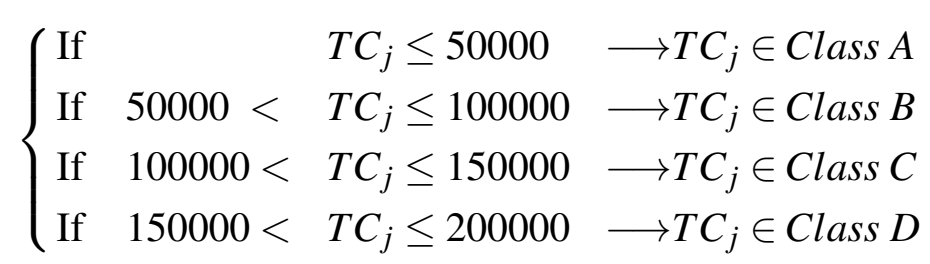

Thereby, we can classify each port in a class for each of the years under study. The next step is to create dummy variables for each interval (see Equation 3). To test our working hypothesis, we will estimate the four coefficients associated with each of the dummy variables. This allows that each category has a value of influence on utility that is not restricted by a functional form established a priori. Once these coefficients are estimated, it will be possible to establish the relation between the attractiveness of the port and its degree of use.

$$
\left\{\begin{array}{llll}
T C_{j}^{A}=1, & \text { if } & T C_{j} \in \text { Class } A ; \text { otherwise } & T C_{j}^{A}=0 \\
T C_{j}^{B}=1, & \text { if } & T C_{j} \in \text { Class } B ; \text { otherwise } & T C_{j}^{B}=0 \\
T C_{j}^{C}=1, & \text { if } & T C_{j} \in \text { Class } C \text {; otherwise } & T C_{j}^{C}=0 \\
T C_{j}^{D}=1, & \text { if } & T C_{j} \in \text { Class } D ; \text { otherwise } & T C_{j}^{D}=0
\end{array}\right.
$$




\section{The proposed model}

\subsection{Framework of discrete choice models}

In the context of Discrete Choice Theory and using common notation, the probability that the shipping $n$ goes through the port $j$ from a choice set $C$ with $J$ alternatives can be expressed as:

$$
P_{n j}=\operatorname{Prob}\left(U_{n j}>U_{n i}, \quad \forall j \neq i\right) \quad C=\{1, \ldots, i, j, \ldots, J\}
$$

where $U_{n j}$ is the utility of the port $j$ for the shipping $n$. However, this utility cannot be completely observed, and consequently is decomposed into two parts: [i] the observed part, $V_{n j}$, representing the modelled effect of variables relating to port alternative $j$ and the shipping $n$ and [ii] the unobserved part (or error term), $\varepsilon_{n j}$, that captures the factors that affect the utility but which are not included in $V_{n j}$.

$$
U_{n j}=V_{n j}+\varepsilon_{n j}
$$

With regard to $V_{n j}$, we propose the most frequent formulation in usual practice: a fixed coefficient utility specification that is lineal in the parameters. It can be expressed as:

$$
V_{n j}=A S C_{j}+\sum_{k=1}^{K} \beta_{k} x_{k n j}
$$

where:

- $A S C_{j}$ : The alternative-specific constants. These constants reflect the utility differences between alternatives when the rest of the $V_{n j}$ expression is equal for all of them.

- $x_{k n j}$ : The $K$ observed variables relating to port alternative $j$ and the shipping $n$.

- $\beta_{k}$ : The generic coefficients (i.e. a unique coefficient for all the alternatives).

Different distributional assumptions on the error term, $\varepsilon_{n j}$, lead to different discrete choice models (see e.g. Garrow (2010) for a recent overview of the models). A common assumption is that $\varepsilon_{n j}$ are independently and identically distributed and follow the extreme value distribution type I or Gumbel distribution with scale parameter $\mu$ greater than zero. To check the basic properties of the Gumbel distribution see e.g. Ben-Akiva and Lerman (1985). This assumption leads to the Multinomial Logit Model (MNL) (Domencich and McFadden, 1975). A common normalization is to set $\mu$ to one, because it is an unidentifiable parameter (see general rules for identifying in Train (2009)). In these terms, the probability that the shipping $n$ goes through the port $j$, presented at the beginning of this section (Equation (4)), takes the following well-known form:

$$
P_{n j}=\frac{e^{V_{n j}}}{\sum_{i=1}^{J} e^{V_{n i}}}
$$


To estimate the values of model parameters $\left(A S C_{j}, \beta_{k j}\right)$ we adopt the maximum likelihood approach which selects the value of coefficients which maximizes the fit of our utility specification to our dataset. If the dataset observations are independent, the likelihood function is given by the product of the probabilities, $P_{n j}$ :

$$
\mathscr{L}\left(A S C_{j}, \beta_{k j}\right)=\prod_{n=1}^{N} \prod_{\forall j \in C}\left(P_{n j}\right)^{y_{n j}}
$$

where $y_{n j}$ indicates whether or not the alternative is chosen; i.e. is one if the shipping $n$ goes through the port $j$ and zero otherwise.

To facilitate the numerical maximization, since the maximums are the same, the log-likelihood or natural logarithm of the likelihood can be taken:

$$
\ln \mathscr{L}\left(A S C_{j}, \beta_{k j}\right)=\sum_{n=1}^{N} \sum_{\forall j \in C} y_{n j} \ln \left(P_{n j}\right)
$$

\subsection{Specification}

The proposed model is:

$$
\begin{aligned}
V_{n j}= & A S C_{j}+\beta_{D O} * D O_{n j}+\beta_{D D} * D D_{n j}+\beta_{C R} * C R_{j}(t)+ \\
& +\sum_{q=1}^{Q} \beta_{T C}^{q} * T C_{j}^{q}(t-1)
\end{aligned}
$$

where:

- $A S C_{j}$ : The alternative-specific constant port $j$.

- $D O_{n j}$ : The distance by road between port $j$ and province of origin of shipping $n$.

- $D D_{n j}$ : The distance for shipping $n$ by maritime routes between port $j$ and country of destination.

- $C R_{j}(t)$ : The number of STS cranes at port $j$, year $t$.

- $T C_{j}^{q}(t-1)$ : The dummy variable of $T C$ for category $q$ in the port $j$, the year $t-1$. We lagged it by one year to avoid endogeneity problems.

\section{Dataset}

Spain's top container peninsular ports are: Valencia, Algeciras, Barcelona and Bilbao. All of them have at least one specific terminal for containers and are located in the same port region (the Spanish part of the Iberian peninsula). Figure 2 shows the evolution of TEUs moved by them for the period under study (2004-2012). As can be seen, the portion of freight traffic of each port has changed.

The data used in this analysis comes from the database of the Spanish Customs Statistics (SCS, 2014). SCS provide information about each single transaction made between Spain and the rest of the world by transport mode. SCS include, among other variables, the Spanish regions of origin (province level), the customs clearance province and the mainland destination. 
Figure 2: Evolution of freight traffic by the four major Spanish container peninsular ports. Data from Spanish Port Authority (2016) (in thousand TEUs).

— Algeciras $\cdots$... Barcelona $\cdot-\cdot$ Bilbao - - Valencia

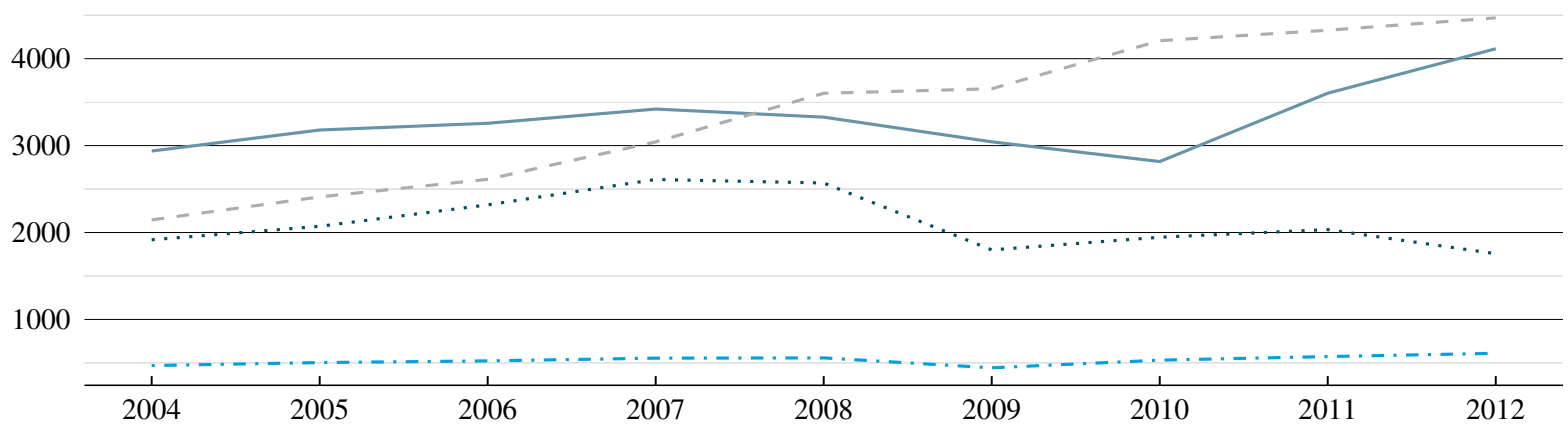

To form our dataset we screened from SCS the data of the four main Spanish container peninsular ports from the years 2004 to 2012. We consider only export flows, container traffic, trade with non-European countries and peninsular provinces. Traffic flows from bordering countries are omitted due to the lack of data, so our dataset only involves national hinterland shipments.

According to the set of data from SCS, covering the years 2004 to 2012, Barcelona was the most selected alternative for container exports to non-European countries, closely followed by Valencia (see Table 2). The port of Algeciras was chosen by scarcely $6 \%$ of the operations, whereas Bilbao was responsible for an even smaller proportion. These data are taken from the perspective of interport competition. It must be pointed out that these data consider only part of the container traffic, whereas to measure the degree of use of the facilities all the traffic that passes through each terminal has been used. The most notable difference occurs in the port of Algeciras. This port attracts less hinterland shipments than Barcelona or Valencia, but it is among the top ten container ports of the European continent and is one of the fifty most important in the world (see the statistics of International Association of Ports and Harbors (IAPH) (2015)) as it is an important transfer port.

Table 2: Container export shipments to non-European countries through the main Spanish peninsular container ports (accumulated total between 2004-2012). Source: Own elaboration from data provided by the SCS (2014).

\begin{tabular}{|c|c|c|}
\hline Port & Shipments & Share $(\%)$ \\
\hline Algeciras & 316136 & $5.82 \%$ \\
\hline Barcelona & 2815136 & $51.82 \%$ \\
\hline Bilbao & 1647 & $0.03 \%$ \\
\hline Valencia & 2299637 & $42.33 \%$ \\
\hline & 5432556 & \\
\hline
\end{tabular}

The Spanish Port Authority provides the characteristics of Spanish port (Spanish Port Authority, 2016). The STS gantry cranes and TEUs moved per port can be found in Traffic Statistics or the Statistical Yearbooks of Spanish ports which, like SCS, are openly available. With respect to the variables linked with the hinterland and the foreland, on the one hand, we com- 
pute the distance by road, between the port and the provincial capital of origin of trade and, on the other hand the mean of the maritime distance by shipping routes between the port of origin and the main port of the country of destination. This maritime distance reflects the vessel's routes. To compute this, we take the mean distance of the most frequently routes according to SeaRates (2015).

\section{Obtained results and discussion}

The models were estimated with BIOGEME (Bierlaire, 2016), software specifically designed for discrete choice models using maximum likelihood estimation. The maximization is performed using the CFSQP algorithm (Lawrence et al., 1997), using a Sequential Quadratic Programming method.

To reach the proposed specification (Equation (10)), we add to the null model (MNL 0) the variables one by one: [i] firstly we consider MNL C, the model with only constants $\left(A S C_{j}\right)$; [ii] we add the distance by road between port and province of origin of trade $\left(D O_{n j}\right)$ in MNL 1; [iii] distance between port and country of destination of trade $(D D n j)$ is added for MNL 2; [iv] number of STS cranes $\left(C R_{j}\right)$ in MNL 3 and [v] TEUs moved by crane $\left(T C_{n j}\right)$ in MNL 4.

The main statistical results are available in Table 3 . We use the likelihood ratio test $(L R)$ (see Ben-Akiva and Lerman, 1985) and, accordingly, in all cases rejected with a confidence over $99 \%$ the possibility that both models are equal, so we accept the inclusion of all the new variables proposed in each model. Two ratio likelihood indexes are used: $\rho^{2}$ and adjusted $\rho^{2}\left(\bar{\rho}^{2}\right)$ (see Ortúzar and Willumsen, 2011). The former takes the null model (MNL 0) as reference and the latter, the model with only constants (MNL C); both vary between 0 (no fit) and 1 (perfect fit).

Table 3: Main statistical results of the estimated models

\begin{tabular}{|c|c|c|c|c|c|}
\hline Models LogLik & $\rho^{2}$ & $\bar{\rho}^{2}$ & Parameters & $L R$ & Comparison \\
\hline MNL $0-7531122$ & & & 0 & & \\
\hline MNL C ${ }^{\text {a }}-4740002$ & 0.3706 & & 3 & -5582240 & MNL 0 - MNL C \\
\hline MNL $1^{b}-2217834$ & 0.7055 & 0.5321 & 4 & -5044336 & MNL C - MNL 1 \\
\hline MNL $2^{c}-2202004$ & 0.7076 & 0.5354 & 5 & -31659 & MNL 1 - MNL 2 \\
\hline MNL 3 d_2 201182 & 0.7077 & 0.5356 & 6 & -1644 & MNL 2 - MNL 3 \\
\hline MNL 4 e-2 194364 & 0.7086 & 0.5371 & 9 & -13636 & MNL 3 - MNL 4 \\
\hline
\end{tabular}

${ }^{\text {a }} V_{n j}=A S C_{j}$

${ }^{\mathrm{b}} V_{n j}=A S C_{j}+\beta_{D O} * D O_{n j}$

${ }^{\mathrm{c}} V_{n j}=A S C_{j}+\beta_{D O} * D O_{n j}+\beta_{D D} * D D_{n j}$

${ }^{\mathrm{d}} V_{n j}=A S C_{j}+\beta_{D O} * D O_{n j}+\beta_{D D} * D D_{n j}+\beta_{C R} * C R_{j}(t)$

e $V_{n j}=A S C_{j}+\beta_{D O} * D O_{n j}+\beta_{D D} * D D_{n j}+\beta_{C R} * C R_{j}(t)+\sum_{q=1}^{Q} \beta_{T C}^{q} * T C_{j}^{q}(t-1)$

The estimated parameters are included in Table 4. All of them are significantly different form zero. The $A S C_{j}$ and the categorical variable $T C_{j}^{q}$ are normalized according to the general rules of identification of discrete choice models (see Train (2009)). With $J$ alternatives, at most $J-1$ alternative-specific constants and $J-1$ categorical variable can be estimated. This is due to the fact that only differences in utility matter, so only parameters that capture differences 
across alternatives can be estimated. It really does not matter which alternative is normalized, but the results should be interpreted with respect to the reference level taken. In our case, Barcelona is the reference alternative $\left(A S C_{B a r}=0\right)$ and for $T C_{j}^{q}$ the reference is category B $\left(\beta_{T C}^{B}=0\right)$.

Table 4: Estimated parameters MNL 4

\begin{tabular}{lrrcr}
\hline Parameter & Variable units & Value & Robust Std. error & Robust $t$-stat \\
\hline$A S C_{A l g}$ & & -1.470 & 0.0047 & -309.82 \\
$A S C_{\text {Bar }}[$ fixed $]$ & & 0.000 & & \\
$A S C_{B i l}$ & & -7.930 & 0.0298 & -265.74 \\
$A S C_{\text {Val }}$ & & -0.558 & 0.0025 & -226.44 \\
$\beta_{D O}$ & $10^{3} \mathrm{~km}$ & -6.870 & 0.0035 & -1964.45 \\
$\beta_{D D}$ & $10^{4} \mathrm{~km}$ & -7.860 & 0.0393 & -199.89 \\
$\beta_{C R}$ & $10^{3} \mathrm{ud}$ & 6.120 & 0.3530 & 17.33 \\
$\beta_{T C}^{A}$ & & -0.286 & 0.0567 & -5.04 \\
$\beta_{T C}^{B}[$ fixed $]$ & & 0.000 & & \\
$\beta_{T C}^{C}$ & & 0.204 & 0.0027 & 74.82 \\
$\beta_{T C}^{D}$ & & -0.585 & 0.0059 & -99.24 \\
\hline
\end{tabular}

Statistics:

Sample size $=5432556$

Number of estimated parameters $=9$

$\ln \mathscr{L}$ initial $=-7531121.749$

$\ln \mathscr{L}$ final $=-2194364.105$

$\rho^{2}=0.7086$

$\bar{\rho}^{2}=0.5371$

As expected, the signs for the coefficients of distance $\left(\beta_{D O}\right.$ and $\left.\beta_{D D}\right)$ are negative. This implies that increases in the values of these variables reduce the utility of that port alternative and, therefore, the probability that it will be chosen. In the same way, the sign of $\beta_{C R}$ is positive, so if a port increases the number of dockside cranes, it enhances its utility and, hence, the probability that it will be chosen. The value of $T C$ coefficients vary among categories (see $\beta_{T C}^{A}, \beta_{T C}^{B}, \beta_{T C}^{C}$ and $\beta_{T C}^{D}$ ). It does not always grow as the degree of use increases. As can be seen in Figure 3, the economies of agglomeration and scale, as well as the network effect, are perceived in class $\mathrm{A}$ and $\mathrm{B}$, while from a point between 100000 and $150000 \mathrm{TEUs} / \mathrm{crane}$ (class $\mathrm{C}$ ) the port attractiveness decreases as the volume of traffic increases. That is, there is a saturation threshold in the degree of use of port facilities beyond which the attractiveness of the port decreases. It can be seen as confirmation of the hypothesis drawn: the degree of use of the port equipment impacts port choice, and there is a threshold beyond which the effect of congestion in the port endowment outweighs the benefits from the economies of agglomeration, scale and network effects. Thus, in relation to the degree of use of its facilities, a saturated port is less attractive. 
Figure 3: TEUs moved by crane vs utility of the ports under study

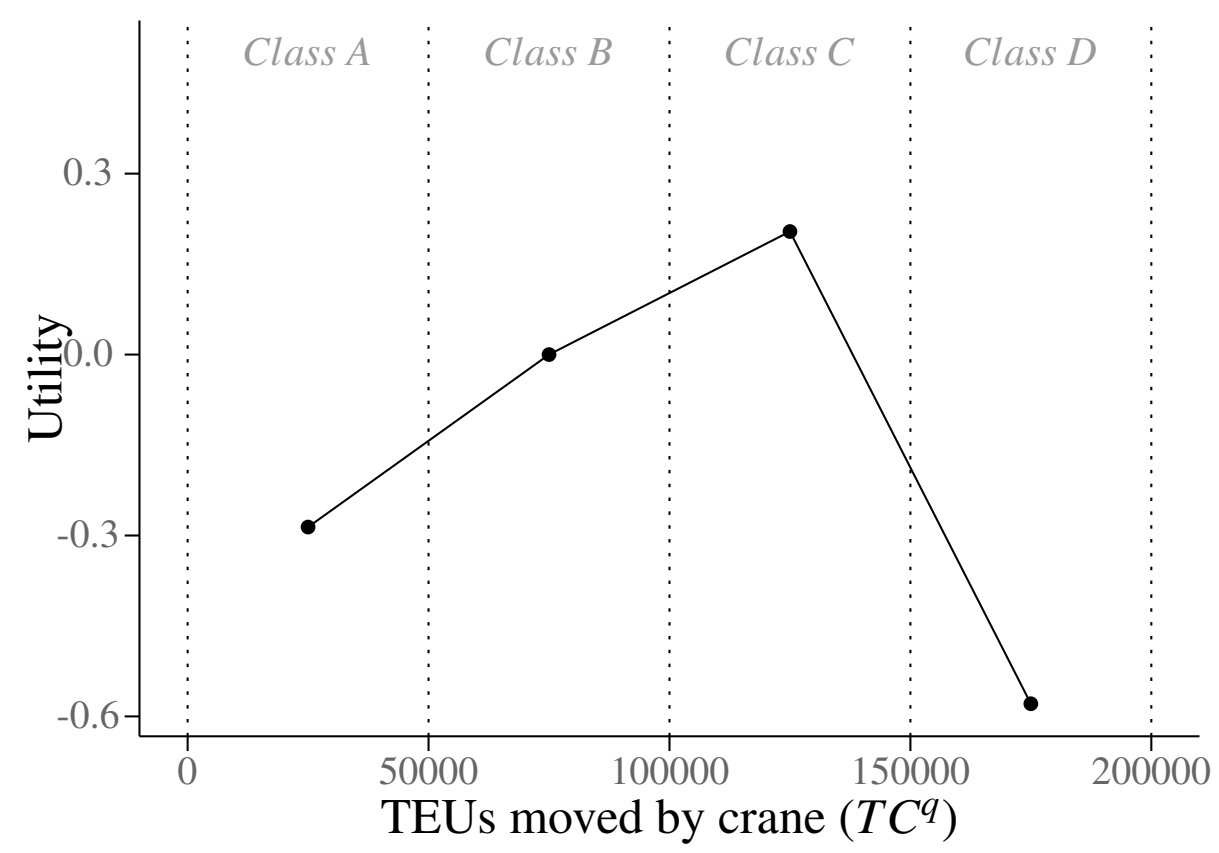

The threshold can be located, more accurately, adjusting the size of the intervals. A greater number of classes has been established, seeking a better distribution of the values between them. The Fisher-Jenks algorithm is used, also known as Fisher's natural breaks classification, implemented in the package classInt (Bivand, 2015). This classification is an improvement of Jenks' natural breaks classification (Jenks and Caspall, 1971), which is a re-implementation of the algorithm described by Fisher in the context of the Choropleth maps (Fisher, 1958). The algorithm iteratively compares the sums of the squared differences between observed values within each class and the averages of the classes. This method minimizes the internal variability of the classes and maximizes the differences between classes, for a number of previously specified intervals. For the case study, the maximum number of intervals that can be obtained is seven. This maximum is marked by the requirements of the DCM that demand a minimum of data and variability in order to be estimated. The classes obtained are detailed below:

$$
\left\{\begin{array}{l}
\text { If } 44346.60<T C_{j} \leq 58905.44 \rightarrow T C_{j} \leq 75375.56 \rightarrow T C_{j} \in \text { Class I } \\
\text { If } 58905.44<T C_{j} \in \text { Class II } \\
\text { If } 75375.56<T C_{j} \leq 91035.13 \longrightarrow T C_{j} \in \text { Class III } \\
\text { If } 91035.13<T C_{j} \leq 107173.80 \longrightarrow T C_{j} \in \text { Class IV } \\
\text { If } 107173.80<T C_{j} \leq 131279.50 \longrightarrow T C_{j} \in \text { Class V } \\
\text { If } 131279.50<T C_{j} \leq 163444.00 \longrightarrow T C_{j} \in \text { Class VI } \\
\text { If } 163444.00<T C_{j} \leq 187017.66 \longrightarrow T C_{j} \in \text { Class VII }
\end{array}\right.
$$

Table 5 shows the results obtained after reclassifying the ports according to the new intervals and re-estimating the model based on them (MNL 5). If compared with MNL 4 (four categories), the $L R$ is positive, justifying the inclusion of the new categories. In Figure 4 the curve is drawn with four and seven categories. It can be seen that the shape remains and the 
threshold is located more accurately (class V, $107173.80<T C_{j} \leq 131279.50$ ), reinforcing the conclusion that the most saturated classes result in lesser utility.

Table 5: Estimated parameters MNL 5

\begin{tabular}{|c|c|c|c|c|c|}
\hline Parámetros & Unidades & Valor & Error Std. rob. & Test-t rob. & p-valor \\
\hline$A S C_{A l g}$ & & -1.190 & 0.0069 & -171.76 & 0.00 \\
\hline$A S C_{\text {Bar }}[$ fixed $]$ & & 0.000 & & & \\
\hline$A S C_{B i l}$ & & -7.750 & 0.0464 & -185.07 & 0.00 \\
\hline$A S C_{V a l}$ & & -0.571 & 0.0031 & -226.44 & 0.00 \\
\hline$\beta_{D O}$ & $10^{3} \mathrm{~km}$ & -6.880 & 0.0035 & -1957.78 & 0.00 \\
\hline$\beta_{D D}$ & $10^{4} \mathrm{~km}$ & -7.940 & 0.0394 & -201.40 & 0.00 \\
\hline$\beta_{C R}$ & $10^{3} u d$ & 1.260 & 0.6530 & 1.92 & 0.05 \\
\hline$\beta_{T C}^{I}$ & & -0.401 & 0.0538 & -7.47 & 0.00 \\
\hline$\beta_{T C}^{I I}[$ fixed $]$ & & 0.000 & & & 0.00 \\
\hline$\beta_{T C}^{I I I}$ & & 0.066 & 0.0068 & 9.66 & 0.00 \\
\hline$\beta_{T C}^{I V}$ & & 0.105 & 0.0085 & 12.42 & 0.00 \\
\hline$\beta_{T C}^{V}$ & & 0.303 & 0.0052 & 58.31 & 0.00 \\
\hline$\beta_{T C}^{V I}$ & & -0.581 & 0.0100 & -58.15 & 0.00 \\
\hline$\beta_{T C}^{V I I}$ & & -1.030 & 0.0108 & -95.40 & 0.00 \\
\hline
\end{tabular}

Statistics:

Sample size $=5432556$

Number of estimated parameters $=12$

$\ln \mathscr{L}$ initial $=-7531121.749$

$\ln \mathscr{L}$ final $=-2189184.187$

$\rho^{2}=0.7093$

$\bar{\rho}^{2}=0.5381$

The value of the saturation threshold obtained for our case study is around 119226 TEUs/crane, for seven classes, and 125000, for four classes. This threshold, beyond which the attractiveness of the port decreases, is close to the average TEUs/crane observed in container terminals: worldwide 123489 (Drewry, 2014) and 125400 Terminals in Latin America and the Caribbean (CEPAL, 2013). 


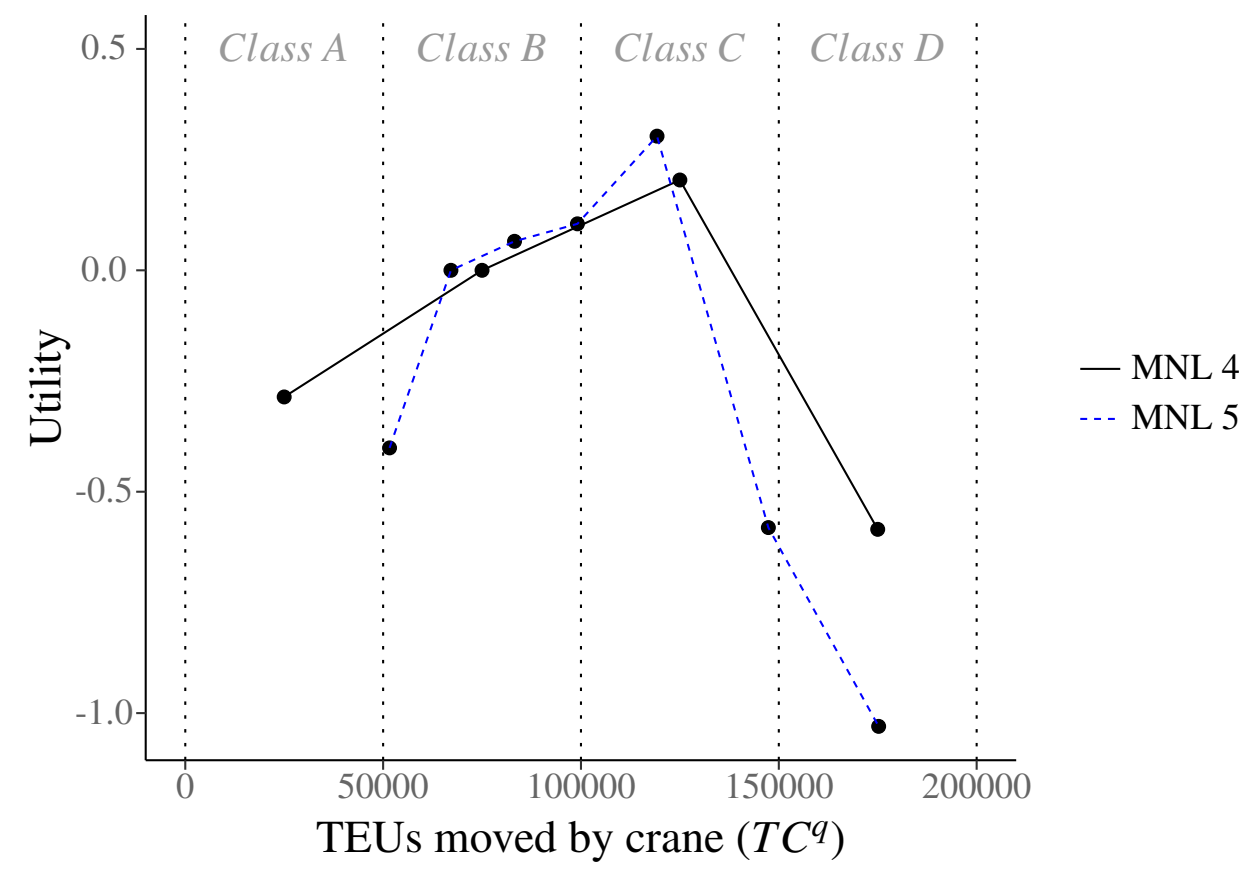

Figure 4: TEUs moved by crane vs utility of the ports under study. MNL4 and MNL 5.

\section{Conclusions}

This paper analyses the competition between the main Spanish peninsular container ports. Results show that firstly, as expected, an increase in the number of STS gantry cranes and a reduction of the distance in origin or to destination, increases the utility of the port and, hence, the probability that it will be chosen. Secondly, the degree of use of port facilities (TEUs per gantry crane) in a port plays a relevant role in port choice behaviour. Finally, there is a threshold beyond which the attractiveness of the port decreases as part of the port endowment becomes saturated. The benefits from the effects of the economies of agglomeration, scale and network are muted by congestion of the facilities.

Therefore, our general finding is that the attractiveness of the port is conditioned by the degree of use of its port facilities or equipment. This is evident in two ways. On the one hand, as explained before, the concentration of traffic has a positive effect on the port's attractiveness which diminishes as the optimal occupancy of the port facilities is approached. On the other hand, the results allow us to go further and see how, if the expansion of port facilities is not accompanied by a growth of traffic, it is also likely that the utility of the port will decrease. That is to say, given a level of traffic, expanding the facilities leads to an increase in costs. If these costs are not offset by a growth of economies of agglomeration, scale and network effects, what was expected to positively enhance the attractiveness of the port, ends up being negative due to the rise of costs.

The results obtained in this paper confirm that the endowment increase of a fixed element of port equipment only reinforces the port attractiveness when it is necessary. Otherwise, it is an incorrect strategy, and the results highlight that it is also wrong to ignore reaching saturation point. Therefore, the Port Authorities should take into account the degree of use of their facilities when defining their competitive strategies and, therefore, their investment expenditure.

The study has dealt with STS gantry cranes but the idea and the result could be extended 
to all elements of the port. Due to the relevance of the obtained results, both from a scholarly and managerial perspective, the analysis could be repeated regarding different elements of the port facilities, such as those related to the berth (TEU per metre of quay) or the yard (TEU per hectare). It could also be interesting for future research to address which of the facilities are more easily saturate so causing bottlenecks, conditioning the attractiveness of the entire installation.

\section{Acknowledgement}

The authors greatly appreciate the anonymous referees for their very valuable comments on this paper. The first author acknowledge the financial support provided by the Deputación da Coruña (A Coruña Province Council) under a research grant for the 2013-2014 course. The second author also acknowledges the financial support provided by the Government of Spain under the project MTM2014-54199-P.

\section{References}

Anderson, C. M., Opaluch, J. J. And Grigalunas, T. A. (2009). The Demand for Import Services at US Container Ports. Maritime Economics \& Logistics, 11(2), 156-185. doi: $10.1057 / \mathrm{mel} .2009 .4$

Ben-Akiva, M. E. And Lerman, S. S. (1985). Discrete Choice Analysis: Theory and Application to Travel Demand. Cambridge, Massachusetts: MIT Press.

BICHOU, K. (2013). An empirical study of the impacts of operating and market conditions on container-port efficiency and benchmarking. Research in Transportation Economics, 42(1), 28-37. doi: 10.1016/j.retrec.2012.11.009

BIERLAIRE. (2016). Estimating choice models with latent variables with PythonBiogeme (Tech. Rep. No. TRANSP-OR 160628). Transport and Mobility Laboratory, ENAC, EPFL.

BIVAND, R. (2015). classInt: Choose Univariate Class Intervals. R package version 0.1-23. Retrieved from https://cran.r-project.org/package=class Int

Blonigen, B. A. AND Wilson, W. W. (2006). International trade, transportation networks, and port choice. In American Economic Association Annual Meeting. Retrieved from http: //www. corpsnets . us/docs /PortDevInternalTransport/PortChoice114 .pdf

CEPAL. (2013). Productividad de activos en terminales de contenedores de América Latina y el Caribe: 2005-2013.

China Ports. (2014). China Ports Yearbook (In Chinese). Shanghai, China: Chinese Port Magazine Publisher.

DIAN. (2012). Registro de importación y exportación de la Dirección Nacional de Impuestos y Aduanas Nacionales. Retrieved from [2016-03-01]http://www.dian.gov.co/ 
Domencich, T. A. And McFadden, D. L. (1975). Urban travel demand: A behavioral analysis. North-Holland Publishing Co.(Reprinted by The Blackstone Company: Mount Pleasant, MI, 1996.), 215.

Drewry. (2014). Container Terminal Capacity and Performance Benchmarks (Tech. Rep.). London: Shipping Consultants Drewry.

Federal Maritime Commissioners (FMC). (2015). U.S. Container Port Congestion and Related International Supply Chain Issues: Causes, Consequences and Challenges (An overview of discussions at the FMC port forums) (Tech. Rep.).

FISHER, W. D. (1958). On Grouping for Maximum Homogeneity. Journal of the American Statistical Association, 53, 789-798.

Garcia-Alonso, L. And Sanchez-Soriano, J. (2009). Port selection from a hinterland perspective. Maritime Economics \& Logistics, 11(3), 260-269. doi: 10.1057/mel.2009.9

Garrow, L. A. (2010). Discrete Choice Modelling and Air Travel Demand: Theory and Applications. Ashgate Publishing, Ltd.

GonzÁlez, M. M. And Trujillo, L. (2009). Efficiency Measurement in the Port Industry: A Survey of the Empirical Evidence. Journal of Transport Economics and Policy, 43(2), 157-192.

Ha, M.-H., Yang, Z., Notteboom, T., NG, A. K. and Heo, M.-W. (2017). Revisiting port performance measurement: A hybrid multi- stakeholder framework for the modelling of port performance indicators. Transportation Research Part E: Logistics and Transportation Review, 103, 1-16. doi: 10.1016/j.tre.2017.04.008

InTERnATIONAL ASSOCIATION OF PORTS AND HARBORS (IAPH). (2015). World Container Traffic Data 2015. Retrieved from [2016-01-01]http://www.iaphworldports .org/iaph/wp-content/uploads/WorldPortTraffic-Data-for-IAPH-using-LL -data2015.pdf

International Transport Forum (ITF). (2009). Port Competition and Hinterland Connections. Paris: OECD Publishing.

InTERnATIONAL TRANSPORT FORUM (ITF). (2014). Time Efficiency at World Container Ports.

Jenks, G. F. And Caspall, F. C. (1971). Error on Choroplethic Maps: Definition, Measurement, Reduction. Annals of the Association of American Geographers, 61(2), 217-244.

Kashina, M., Thill, J.-C. And Depken, C. A. (2016). Shipping route choice across geographies: Coastal vs. landlocked countries. Transportation Research Part E: Logistics and Transportation Review, 91, 1-14. doi: 10.1016/j.tre.2016.03.012

LAWrence, C., Zhou, J. And Tits, A. (1997). User's guide for CFSQP version 2.5: A $C$ code for solving (large scale) constrained nonlinear (minimax) optimization problems, generating iterates satisfying all inequality. Technical Report TR-94-16r constraints (Tech. Rep.). College Park: Institute for Systems Research, University of Maryland. 
Malchow, M. B. AND KANAFAnI, A. (2001). A disaggregate analysis of factors influencing port selection. Maritime Policy \& Management, 28(3), 265-277.

Martínez Moya, J. And Feo Valero, M. (2016). Port choice in container market: a literature review. Transport Reviews, 1-22.

MCFADDEN, D. (1973). Conditional logit analysis of qualitative choice behavior. In Frontiers in Econometrics (pp. 105-142).

McFAdDEn, D. (2001). Economic choices. Nobel Lecture, December 2000. The American Economic Review, 91(3), 351-378.

Mohring, H. (1972). Optimization and Scale Economies in Urban Bus Transportation. The American Economic Review, 62(4), 591-604.

NiR, A.-S., Lin, K. AND Liang, G.-S. (2003). Port choice behaviour-from the perspective of the shipper. Maritime Policy \& Management, 30(2), 165-173. doi: 10.1080/ 0308883032000069262

NuÑEZ, O. D. AND SÁNCHEZ, R. J. (2006). Indicadores de productividad para la industria portuaria. Aplicación en América Latina y el Caribe (Tech. Rep.). Santiago de Chile: División de Recursos Naturales e Infraestructura. Comisión Económica para América Latina y el Caribe (CEPAL).

Ortúzar, J. D. D. And Willumsen, L. G. (2011). Modelling Transport (Fourth ed.). Chichester, UK: John Wiley \& Sons, Ltd.

Parola, F., Risitano, M., Ferretti, M. and Panetti, E. (2016). The drivers of port competitiveness: a critical review. Transport Reviews, 1-23.

SCS. (2014). Spanish Customs Statistics. Retrieved from [2016-03-01]http://www .agenciatributaria.es

SEARATES. (2015). Freight Exchange platform. Retrieved from [2016-03-01]www . searates . com

SlaCK, B. (1985). Containerization, inter-port competition, and port selection. Maritime Policy \& Management, 12(4), 293-303. doi: 10.1080/03088838500000043

SPAnish Port AUTHORITY. (2016). Traffic Statistics and Statistical yearbooks of the Spanish Port Authority. Retrieved from [2016-03-01]http: //www . puertos . es

Steven, A. B. And Corsi, T. M. (2012). Choosing a port: An analysis of containerized imports into the US. Transportation Research Part E: Logistics and Transportation Review, $48(4), 881-895$.

Tiwari, P., Itoh, H. And Doi, M. (2003). Shippers' Port and Carrier Selection Behaviour in China: A Discrete Choice Analysis. Maritime Economics \& Logistics, 5(1), 23-39. doi: 10.1057/palgrave.mel.9100062 
Tongzon, J. L. And SAwAnt, L. (2007). Port choice in a competitive environment: from the shipping lines' perspective. Applied Economics, 39(4), 477-492. doi: 10.1080/ 00036840500438871

Tovar, B., Jara-Díaz, S. And Trujillo, L. (2003). Production and cost functions and their application to the port sector : a literature survey (No. 3123). Retrieved from http://documents.worldbank.org/curated/en/635851468778198532/ Production-and-cost-functions-and-their-application-to-the-port-sector -a-literature-survey

Tovar, B., JARA-DíAz, S. AND Trujillo, L. (2007). Econometric estimation of scale and scope economies within the Port Sector: a review. Maritime Policy \& Management, 34(3), 203-223. doi: 10.1080/03088830701342932

Train, K. (2009). Discrete choice methods with simulation (2nd ed.). Cambridge University Press.

UNCTAD. (2015). Review of Maritime Transport.

Vega, L. A., Cantillo, V. M. And Arellana, J. A. (2014). Modelación de la elección de puerto desde una perspectiva desagregada: un análisis para los puertos colombianos. Santander: XVIII Congreso Panamericano de Ingeniería de Tránsito, Transporte y Logística (PANAM 2014).

Veldman, S., Garcia-Alonso, L. And LiU, M. (2015). Testing port choice models using physical and monetary data: a comparative case study for the Spanish container trades. Maritime Policy \& Management, 1-14.

Veldman, S., Garcia-Alonso, L. And Vallejo-Pinto, J. Á. (2011). Determinants of container port choice in Spain. Maritime Policy \& Management, 38(5), 509-522. doi: 10.1080/03088839.2011.597450

Veldman, S., Garcia-Alonso, L. and Vallejo-Pinto, J. A. (2013). A port choice model with logit models: a case study for the Spanish container trade. International Journal of Shipping and Transport Logistics, 5(4/5), 373.

Veldman, S. And Gopkalo, O. (2011). A Model on Port Basin Choice with Russian Container Trade. Proceedings of the International Forum on Shipping, Ports and Airports (IFSPA) 2010.

Wilmsmeier, G., Tovar, B. And SAnchez, R. J. (2013). The evolution of container terminal productivity and efficiency under changing economic environments. Research in Transportation Business and Management, 8, 50-66.

YANG, J., WANG, G. W. AND Li, K. X. (2016). Port choice strategies for container carriers in China: a case study of the Bohai Bay Rim port cluster. International Journal of Shipping and Transport Logistics, 8(2), 129.

Yeo, G.-T. G., NG, A. K. A., Lee, P. T.-W. P. And Yang, Z. (2014). Modelling port choice in an uncertain environment. Maritime Policy \& Management, 41(3), 251-267. doi: $10.1080 / 03088839.2013 .839515$ 